seeds sent by geneticists in all parts of the world who are investigating these genera. Exhibits illustrating fruit breeding will be shown at the Agricultural Experiment Station, Geneva, New York, and an extensive series concerning human genetics is being arranged in connexion with the Third International Congress of Eugenics, to be held in New York immediately before, on Aug. 21-23. A long series of animal exhibits, including domestic manmals and birds, fishes, insects, and molluses, is also in preparation, the assembling of each group being in charge of a different person. Arrangements have been made for delegates to book passage on s.s. Westernland at a special rate of 200 dollars for the return voyage.

SugGestrons have been made that the Congress should be postponed until world conditions improve, but Dr. C. C. Little, of Bar Harbor, Maine, SecretaryGeneral of the Congress, has issued a communication stating that the Council, after prolonged consultation, has decided not to postpone the Congress. Among the factors which influenced the Council in deciding to carry on the arrangements as originally intended, are the facts that a number of prominent European geneticists have already indicated their intention to attend, that a large number of lectureships for visitors to the Congress are being arranged by American universities, that obligations have already been made and commitments undertaken, and that early improvement in economic conditions is uncertain, making postponement inadvisable. Now that the matter is finally settled, it is hoped that all geneticists who can possibly do so will plan to attend.

\section{Electric Equipment of the Dolomites Railway.}

THe narrow gauge Dolomites railway which joins Calalzo, in the Piave valley, to Dobbiaco, a distance of about forty miles, has now been working very satisfactorily for over two years. As the railway passes through Cortina d'Ampezzo, it is much frequented by tourists. The railway is operated by electricity and so there is no smoke and steam to detract from the beauty of the scenery. Fears were entertained in case, during heavy falls of snow, water would get into the motors and interfere with their working. A special arrangement was therefore devised for them so that when necessary they could be made 'enclosed' motors. Even in snow-clearing operations, when they were considerably overloaded, the motors suffered no damage. In the Brown Boveri Review for October, A. Brodbeck gives an account of the electric equipment of this railway. It receives its power from a three-phase network at Calalzo at a pressure of 18,000 volts; but for operating the railway, direct current at 2700 volts is adopted. This is done by the use of only one substation situated near Cortina, a little more than half-way from the power terminus. The conversion of the alternating to direct current is done at the substation by means of two mercury are rectifiers each of 11,000 kilowatts capacity at 3000 volts. It is interesting to learn that a momentary load of 200 per cent does them no harm, and that they can withstand a 25 per cent overload for half an hour. Owing to the comparatively small currents they take, they require little space and their efficiency is extremely high, being $99 \cdot 1$ per cent over a large range of output. The use of rectifiers in railway plants is increasing, and we anticipate a rapid increase in the future.

\section{Novel Slot Electricity Meter.}

We learn from A.E.G. Progress for October that many hotel, boarding-house, and convalescent-home keepers now instal in their bedrooms a special slot meter to collect the cost of the electric energy consumed by the visitor. It is not uncommon for travellers to carry about with them all kinds of portable electrical appliances which are readily connected to the plugs in the bedroom, notwithstanding the printed regulations to the contrary. This sometimes leads to the blowing of fuses and is a source of fire risk to the building. It is therefore now not uncommon to put slot meters in the bedrooms, so that by the insertion of a coin the guest purchases a given amount of energy. Unlike an ordinary prepayment meter, the coin mechanism can be returned to the ' off' position by resetting a simple device. In this way the new visitor cannot consume at the expense of the previous one any energy that still may be available. The resetting device is actuated by a key, kept by the proprietor, who cancels for his own benefit the credit still due to the departing visitor. The company which makes this meter suggests that the constant source of revenue obtained in this way should be utilised to make the rooms more comfortable, and furnish them with plug points for all kinds of electric devices.

\section{Indian Antiquities.}

SIR EDWARD GaIT's review of British research work in India in the fields of archæology, philology, and ethnology in his address to the first meeting of the Royal Society of Arts in the current session (Jour. Roy. Soc. Arts, Nov. 13) records a remarkable achievement, especially when it is taken into account that such research, often demanding intense application, in the majority of cases has been no more than the distraction of a busy official career. India can now boast of an ancient civilisation and a literature, of which the older elements may go back so far as 2000 B.C.; but when British rule began in the eighteenth century, Sanskrit literature and lore had lapsed into disrepute, the ancient monuments had been allowed to fall into decay, and the course of events in the Hindu period had been forgotten. From the time when the study of Indian antiquities was placed on an organised basis by Sir William Jones, who had gone to India as a judge of the Supreme Court in 1783, and the Asiatic Society of Bengal was founded, British officials have engaged. in all branches of Indian studies with enthusiasm. Forgotten scripts, forgotten languages, and even forgotten empires have been rescued from oblivion, while the investigation of the customs, races, and religions of the people of India has been pursued in a scientific spirit without reference to racial or political prepossessions. Thanks largely to the efforts of

No. 3244, VoL. 129] 
Lord Curzon, ancient monuments have been restored and the care of antiquities made a matter of administrative charge. It is to be regretted that Sir Edward Gait has to record a falling off in the number of British civil servants who now devote themselves to such studies; but on the other hand there is a measure of compensation in the fact that the number of natives of India who are interested in the history and antiquities of their own country is on the increase.

\section{Birds of Paradise.}

IN the Bird House and the small Tropical House adjoining it, the Zoological Society of London now exhibits a dozen species of birds of paradise, several of them recent arrivals along with the rare Matschie's tree kangaroo (see Nature, Dec. 12, p. 996), also coming from the Rawlinson Mountains in north - east New Guinea. Most noteworthy is the Emperor of Germany's Bird of Paradise (Paradisea gulielmi), a species new to the collection; it bears a general resemblance to the well-known Lesser Emerald Bird of Paradise, but has the crown as well as the throat green, and the side-plumes shorter and of a different and less downy texture, more recalling the nuptial plumes of the egrets. Among those species that have been in the collection some time, special mention may be made of the Twelve-wired (Seleucides ignotus), because of the pecularity it exhibits of having the legs bare for some distance above the hock, as in a wading-bird. This peculiarity is shared by a very different bird from the same zoological region and also in the collection, the great black Palm-eockatoo (Microglossus aterrimus); this is noteworthy, for neither affinity nor habits can be involked for the explanation of this nudity in these two species. A very humble bird by comparison, but also of much scientific interest, is a newly received specimen of the melanistic mutant of the blackcap: this variation, which is found in the Canaries and Azores, has been known for upwards of a century, and is called Heineken's Blackcap. The bird is on view in one of the small cages in the Bird House.

\section{British Empire Hardwoods and Turnery.}

IN Museum No. 1 in the Royal Botanic Gardens, Kew, a temporary exhibit of articles turned from Empire hardwoods by the skilled hands of Mr. A. L. Hetherington, assistant secretary in the Department of Scientific and Industrial Research, has been arranged. While indulging his hobby of turnery, Mr. Hetherington also carried on important research, for he worked upon some eighty different kinds of Empire woods, many of which are new to the turner, the results of his work being demonstrated by excellently carved boxes, chalices, tazzas, goblets, dishes, ash trays, and other articles. Particularly beautiful are a chalice made from sapodilla wood (Achras Sapota), two tazzas made of African blackwood (Dalbergia melanoxylon), a goblet of bulletwood (Mimusops littoralis), a string box of puriri (Vitex littoralis), and two match stands of gidgee (Acacia Cambagei). Mr. Hetherington has added to the value of his demonstrative work by writing an account of the various kinds of wood used, with particulars of their peculiar working properties. This book has recently been published by the Empire Marketing Board under the title "British Empire Hardwoods from the Point of View of Turnery." After discussing the properties of eighty kinds of wood, he goes into further particulars about those he considers of greatest importance for ornamental turning. All who are interested in wood turnery should make an effort to visit Kew within the next few weeks and inspect this interesting collection.

\section{Forest Survey by Aeroplane.}

$I_{N}$ the development and protection of Canadian forests, aircraft have come to play a most important part. The Canadian Surveyor for October in a general account of aviation in Canada explains how aerial photography is used to show the character, distribution, and accessibility of the timber, thus facilitating exploitation on sound lines. Even more valuable is the use of air patrols for noting forest fires, and of air transport in carrying crews and equipment for extinguishing the fires. In Ontario alone during the year 1929 more than three hundred fires were thus detected. Aircraft are also used in combating insect and other pests. These attempts are still in an experimental stage, but the results so far are promis. ing. Areas of fir and spruce affected by spruce budworm and of hemlock and balsam affected by hemlock looper have been dusted with calcium arsenate from the air. The method is certainly cheap and fairly thorough. Experiments in Manitoba have shown the effectiveness of dusting wheat with sulphur in order to fight the destructive wheat stem rust. Aircraft are also being used to expose spore traps, in an endeavour to determine the spread of wheat rust and white pine blister rust.

\section{Quantity of Matter in the Universe.}

IN the discussions taking place at the present time on the structure of the universe, the amount of matter distributed throughout the whole of space is determined by calculating the total mass of existing protons and electrons. In all the celestial bodies revealed by the means of observation yet available, the whole number of these corpuscles is found to be $10^{79}$. All other hypotheses must, therefore, be based on this figure and on the dimensions of the radius of the universe. In a note by Prof. Gianfranceschi, broadcast from the Vatican on Nov. 26, it was pointed out that limitation of the consideration of this question to that of the matter constituting the corpuscles is scareely justifiable. Protons and electrons represent a special, but not the original, form of matter. They exert forces of attraction and repulsion originating in their character as electrified corpuscles and in their masses, that is, in measurable magnitudes. The possibility of the transformation and formation of the corpuscles must, however, be assumed. In considering such changes, not merely the energy variations but also the inertia must be taken into account, and any theory of the universe which may be formulated, whether static or dynamic, should be based on these

No. 3244, VoL. 129] 